Ann. Biol. anim. Bioch. Biophys., 1978, 18 (2 B), 471-476.

\title{
In vitro exchange between the follicle and its culture medium
}

by Y. MÉNÉZO, M. GÉRARD *, D. SZÖLLÖSI *, C. THIBAULT **

I.N.R.A., Laboratoire de Biologie, I.N.S.A. Bt. 406 , Villeurbanne 69621, France

* Station de Physiologie animale, I.N.R.A., 78350 Jouy en Josas, France

** Université de Pierre et Marie Curie, Paris.

Summary. Two techniques for culturing bovine de Graaf follicle were compared. The « continuous flow » technique permitting better incorporation of amino acids was used.

As cAMP, puric and pyrimidic bases could pass from the follicle into the culture medium. Glucose consumption and lactate accumulation did not vary significantly in relation to maturation stage or after the addition of HCG into cultures with PMS.

High molecular weight proteins were found to migrate from the follicular fluid into the culture medium if the follicle remained healthy up to the end of culture. Atresia totally suppressed this permeability.

Meiosis may resume in vitro in intrafollicular oocytes, depending upon whether or not gonadotropins are added in the culture medium (rat : Tsafrifri et al., 1972 ; rabbit : Thibault and Gérard, 1973 ; monkey and calf: Thibault, Gérard and Ménézo, 1976 ; sheep : Moor and Trounson, 1977). Except for the mouse (Mukherjee, 1972), it is now well established that only these follicle-enclosed mature oocytes are able to support normal embryonic development after fertilization (rabbit: Thibault, Gérard and Ménézo, 1975b; sheep : Moor and Trounson, 1977). However, these results were obtained with large antral follicles, relatively scarce in the ovary.

In order to promote the long-term culture necessary for the maturation of middlesized follicles, we developed a continuous-flow superfusion technique mimicking the physiological sifuation in the ovary (Ménézo, Gérard and Thibault, 1976). As in vivo, the whole growing follicle is entirely bathed in a continuously flowing medium and metabolic exchange occurs all around the follicle.

This study presents data on melabolic activity and compares the continuous-flow technique with that of organ culture grid. 


\section{Material and methods.}

Calf and macaque follicles were collected according to our current technique (Thibault et al., 1975a). They were cultured either in organ grid conditions or employing the superfusion technique. The gas phase was 57 p. $100 \mathrm{O}_{2}-5$ p. $100 \mathrm{CO}_{2}$ 38 p. $100 \mathrm{~N}_{2}$.

The culture medium, based upon cow follicular fluid, was entirely synthetic* (Ménézo, 1976). In some experiments Ficoll 70 (Pharmacia) was substituted for BSA. Different gonadotropins were always added (PMS and PMS + HCG). For biochemical studies, we analyzed the medium before and after 50-hrs culture. Free amino acid analyses were performed using ion-exchange chromatography on the Optica aminolyzer. Puric and pyrimidic bases, CAMP and AMP were detected and identified using HPLC. Glucose was determined using the hexokinase method and lactate using LDH, after precipitation with perchloric acid. Electrophoreses were performed for nonenzymatic proteins using the Pharmacia PAA 4/30 system allowing separation according to molecular weight (MW). Hydrolytic enzymes were detected with the colorimetric method of Monget (1975) and dehydrogenases with a modified method of Altmann (1969).

\section{Results and discussion.}

After 52 hrs of culture, follicle diameter increased by 5 to 10 p. 100 when we used superfusion.

Free amino acids (table 1). The uptake of free amino acids is 3 to 39 times higher with superfusion than on grid. The high rate of glycine and glutamic + glutamine

\section{TABLE 1}

Comporative study of free AA consumption ( $\mathrm{nMoles} / \mathrm{h} / \mathrm{follicle}$ ) 6 follicles per technique

\begin{tabular}{|c|c|c|c|}
\hline Amino-acids & $\begin{array}{l}\text { Superfusion } \\
(\mathrm{m})\end{array}$ & $\begin{array}{l}\text { Organ culture } \\
(\mathrm{m})\end{array}$ & Super/org \\
\hline 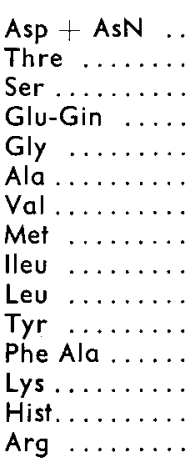 & $\begin{array}{r}29 \\
21 \\
19 \\
248 \\
597 \\
53 \\
22 \\
4 \\
16 \\
18 \\
15 \\
13 \\
26 \\
14 \\
22\end{array}$ & $\begin{array}{r}3.5 \\
1.7 \\
0.5 \\
17.7 \\
33.8 \\
4.8 \\
7.2 \\
1.3 \\
2.3 \\
3.2 \\
0.8 \\
1.1 \\
3.0 \\
1.2 \\
3.1\end{array}$ & $\begin{array}{l}8.3 \\
12 \\
38.8 \\
14 \\
17.7 \\
11 \\
3.1 \\
2.9 \\
6.8 \\
4.8 \\
18.3 \\
11.6 \\
8.4 \\
11.9 \\
7.2\end{array}$ \\
\hline
\end{tabular}

* API System, 38390 Montalieu, Vercieu, France. 
consumption is probably related to their possible utilization for the synthesis of nuclear material. This metabolic increase leads neither to degeneration (Thibault, Gérard and Ménézo, 1975b) nor to dedifferentiation, as sometimes observed in immerged cultures.

Bases and nucleotids. Attention has been focussed on the burst of CAMP in vivo after LH surge. Effectively, cAMP was identified in culture media of macaque and calf follicles, even when oocytes remained in prometaphase or metaphase 1 stages. However, all puric and pyrimidic bases are also found.

Glucose and lactate (tables 2 and 3). Glucose uptake by 3 to $5 \mathrm{~mm}$ calf follicles is about 60 to $80 \mu \mathrm{g} / \mathrm{hr}$. Lactate accumulation is from 12 to $24 \mu \mathrm{g} / \mathrm{hr}$. However, glucose uptake and lactate accumulation are statistically unrelated to the oocyte maturation stage reached and to the gonadotropin environment in the culture medium (PMS or PMS + HCG). Similar observations were made for the rat by Tsafriri ef al. (1976a) and Hillensjö (1976).

TABLE 2

Glucose uptake and lactate accumulation according to maturation stage reached in 50-hr culture

\begin{tabular}{|c|c|c|c|c|c|}
\hline $\begin{array}{l}\text { Maturation stage } \\
\text { reached }\end{array}$ & $\begin{array}{l}\text { Follicles } \\
\text { cultured }\end{array}$ & \multicolumn{2}{|c|}{$\begin{array}{l}\text { Glucose uptake } \\
\mu \mathrm{g} / \mathrm{hr} \quad(\sigma)\end{array}$} & \multicolumn{2}{|c|}{ Lactate accumulation } \\
\hline $\begin{array}{l}\text { Dictyate or prometaphase. } \\
\text { Met. } 1 \quad \ldots \ldots \ldots \ldots \ldots \ldots \\
\text { Met. } 2 \ldots \ldots \ldots \ldots \ldots \ldots\end{array}$ & $\begin{array}{l}6 \\
8 \\
6\end{array}$ & $\begin{array}{l}61.2 \\
77.9 \\
82\end{array}$ & $\begin{array}{l}(13.3) \\
(13.8) \\
(13.3)\end{array}$ & $\begin{array}{l}22.1 \\
24.3 \\
11.9\end{array}$ & $\begin{array}{l}(5.2) \\
(4.2) \\
(3.8)\end{array}$ \\
\hline
\end{tabular}

TABLE 3

Sugar metabolism according to hormonal treatment in 50-hr culture

\begin{tabular}{|c|c|c|c|c|c|}
\hline $\begin{array}{l}\text { Hormonal treatment } \\
\text { in culture }\end{array}$ & $\begin{array}{l}\text { Follicles } \\
\text { cultured }\end{array}$ & $\begin{array}{l}\text { Glucose } \\
\mu \mathrm{g} / \mathrm{hr}\end{array}$ & $\begin{array}{l}\text { uptake } \\
\qquad(\sigma)\end{array}$ & $\begin{array}{l}\text { Lactate } \\
\mu \mathrm{g} / \mathrm{hr}\end{array}$ & $\begin{array}{l}\text { ulation } \\
\quad(\sigma)\end{array}$ \\
\hline $\begin{array}{l}\text { PMS }+ \text { HCG } \ldots \ldots \ldots \ldots \\
\text { PMS } \ldots \ldots \ldots \ldots \ldots \ldots\end{array}$ & $\begin{array}{l}12 \\
12\end{array}$ & $\begin{array}{l}90.3 \\
73.0\end{array}$ & $\begin{array}{l}(12) \\
(13)\end{array}$ & $\begin{array}{l}19.1 \\
21.4\end{array}$ & $\begin{array}{l}(3.1) \\
(4.2)\end{array}$ \\
\hline
\end{tabular}

Macromolecules (table 4, fig. 1). Electrophoresis : proteins migrate towards the medium from healthy follicles, whatever maturation stage has been reached. Main proteins transferred from calf follicle have a MW between 80000 and 100000 , although lower $\mathrm{MW}$ proteins also shift. A similar transfer also occurs with macaque follicles, but proteins heavier than 150000 are also transferred.

Culture in media using Ficoll instead of BSA showed that follicular albumin (MW 65 000) also migrates from the follicle. Comparison of electrophoretic mobilities and ouchterlony immunodiffusion indicate that the proteins found in the culture medium seem to come from the follicular fluid and are not neosynthesized. Our observations may be related to the work of Tsafriri et al. (1976b) on the inhibitory 


\section{TABLE 4}

Enzymes found in calf control follicular fluid and in the culture medium after 50-hr culture

\begin{tabular}{|c|c|c|}
\hline & $\begin{array}{l}\text { Before culture } \\
\text { (follicular fluid) }\end{array}$ & $\begin{array}{l}\text { After culture } \\
\text { (medium) }\end{array}$ \\
\hline 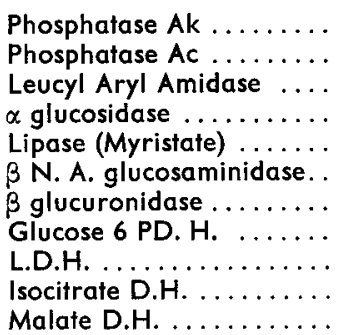 & $\begin{array}{l}+ \\
+ \\
+ \\
+ \\
0 \\
+ \\
+ \\
+ \\
+ \\
+ \\
+\end{array}$ & $\begin{array}{l}+ \\
+ \\
+ \\
+ \\
+ \\
+ \\
0 \\
+ \\
+ \\
0 \\
+\end{array}$ \\
\hline
\end{tabular}

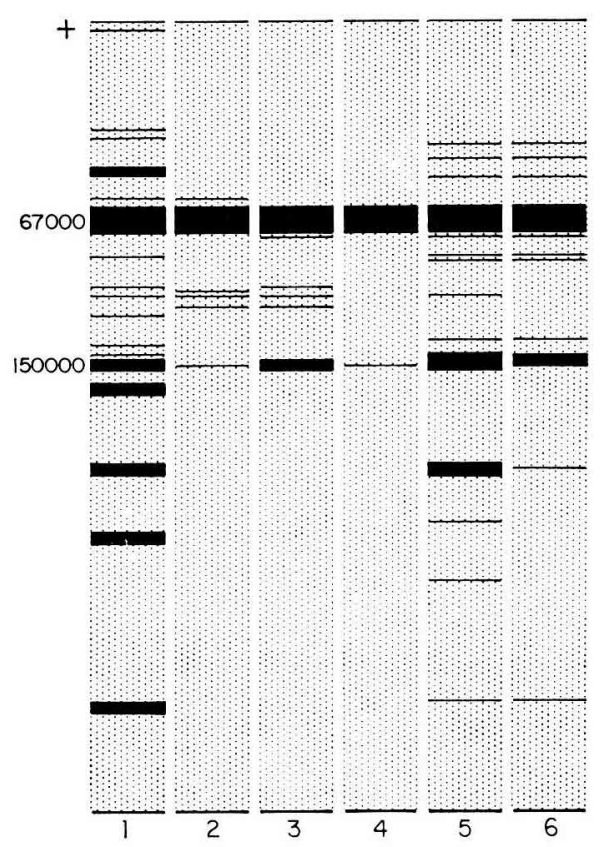

FIG. 1. - Acrylamid gel electrophoresis of follicular fluid.

1 : Calf follicular fluid ; 2 : Medium (with BSA) after $50 \mathrm{hrs}$ of calf follicle culture (meiosis reaches $M I$ ) ; 3 : Medium with Ficoll after $50 \mathrm{hrs}$ of calf follicle culture (meiosis resumes up to $M \mathrm{II}$ ) ; 4 : Control medium (with BSA) or medium after culture of an atretic calf follicle ; 5 : Macaque follicular fluid before culture ; 6 : Medium after a $50 \mathrm{hrs}$-culture of a macaque follicle (meiosis stage : $M I$ ).

$67,000: B S A ; 150,000:$ BSA dimer. 
effect of follicular fluid on meiosis resumption. Before ovulation in healthy follicles, the inhibitor is no longer synthesized and may leave the follicular fluid by the transfer mechanism described.

Malic dehydrogenase, not present in the follicle at the beginning of culture, appears in the medium. Except for the cumulus and the oocyte (Dekel ef al., 1976), the presence of this enzyme could confirm that gonadotropins enhance the aerobic pathway. However, a simple release from the theca cells is not completely excluded.

Macromolecular permeability was severely impaired when cultured calf follicles became atretic.

Enzymes. As expected some enzymes pass through the follicular wall; this is the case of alkaline phosphatase and non-specific esterases. However, the same MW dependence is also observed since $\beta$ glucuronidase (MW 210 000) was not detected in culture media. Isocitrate dehydrogenase (MW 300000 ) shows a similar scheme.

\section{Conclusions.}

Continuous-flow superfusion technique was an improvement over the organ culture grid one. There was an increase of mitotic index and of follicle volume related to augmented amino acid consumption. Corona cell reaction was initiated.

However, the percentage of metaphase II at the end of culture remained under 50 p. 100 . So, it seems for now that the oocyte maturation process cannot be related to a simple metabolic test or to steroid synthesis (Lieberman et al., 1976). Macromolecular transfer from the follicle, impaired by atresia, could be an intraovarian mechanism for the regulation of ovarian follicle population in vivo (Peters, 1973). Very little is known, either in vivo or in vitro, about normal transfer from the follicle. A signal of complete cytoplasmic and nuclear maturation, which could be detected by metabolite(s) analysis in the culture medium, is yet to be found.

27 e Congrès international des Sciences physiologiques, Symposium « Germ and somatic cell interaction 》 Paris, 21-23 juillet 1977.

Résumé. Deux techniques de culture du follicule de de Graaf bovin ont été comparées. La technique « en continu » qui permet une meilleure incorporation des aminoacides a été retenue.

Il apparaît que, comme l'AMP cyclique, les bases puriques et pyrimidiques peuvent passer du follicule vers le milieu de culture. La consommation de glucose ef l'accumulation de lactate ne varient significativement ni en fonction du stade de maturation ni par l'addition d'HCG dans les cultures avec PMS.

Des protéines de poids moléculaires élevé peuvent migrer du liquide folliculaire vers le milieu de culture si le follicule demeure sain à la fin de la culture. L'atrésie supprime totalement cette perméabilité.

\section{References}

ALTMANN F. P., 1969. The use of eight different tetrazolium salts for the quantitative study of pentose shunt dehydrogenation. Histochem., 19, 363-374.

DEKEL N., HULTBORN R., HILLENSJO T., HAMBERGER L., KRAICER P., 1976. Effect of luteinizing hormone on respiration of the preovulatory cumulus cophorus of the rat. Endocrinology, 98, 498-504. 
HILLENSJO T., 1976. Oocyte maturation and glycolysis in isolated preovulatory follicles of PMS injected immature rats. Acta endocr., 82, 809-830.

LIEBERMAN M. E., TSAFRIRI A., BAUMINGER S., COLLINS W. P., AHRÉN K., LINDNER H. R., 1976. Oocytic meiosis in cultured rat follicles during inhibition of steroidogenesis. Acto endocr., 83, 151-157.

MÉNÉZO Y., 1976. Milieu synthétique pour la survie et la maturation des gamètes et pour la culture de l'œuf fécondé. C. R. Acad. Sci. Paris, sér. D, 282, 1967-1970.

MÉNÉZO Y., GÉRARD M., THIBAULT C., 1976. Culture du follicule de Graaf bovin dans un système à courant liquide et gazeux continu. C. R. Acad. Sci., Paris sér. D, 283, 1309-1311.

MONGET D., 1975. Différences d'activités enzymatiques entre deux lignées cellulaires d'insectes, Antherea eucalypti et Malacosoma disstria (Lepidoptera). C. R. Acad. Sci. Paris, sér. D, 281, 651-654.

MOOR R. M., TROUNSON A. O., 1977. Hormonal and follicular factors affecting maturation of sheep oocytes in vitro and their subsequent developmental capacity. J. Reprod. Fert., 49, 101-109.

MUKHERJEE A. B., 1972. Normal progeny from fertilization in vitro of mouse oocytes matured in vitro and spermatozon capacited in vitro. Nature, 237, 397-398.

PETERS H., 1973. Development and atresia of follicles in the immature mouse. Ann. Biol. anim. Bioch. Biophys., 13, 167-175.

THIBAULT C., GÉRARD M., 1973. Cytoplasmic and nuclear maturation of rabbit oocytes in vitro. Ann. Biol. anim. Bioch. Biophys., 13, 145-156.

THIBAULT C., GÉRARD M., MÉNÉZO Y., 1975a. Acquisition par l'ovocyte de lapine et de veau du facteur de décondensation du noyau du spermatozoïde fécondant (MPGF). Ann. Biol. anim. Bioch. Biophys., 15, 705-714.

THIBAULT C., GÉRARD M., MÉNÉZO Y., 1975b. Preovulatory and ovulatory mechanisms in oocytes maturation. J. Reprod. Fert., 45, 605-610.

THIBAULT C., GÉRARD M., MÉNÉZO Y., 1976. Nuclear and cytoplasmic aspects of mammalian oocyte maturation in vitro in relation to follicle size and fertilization, 233-240. In HUBINONT P. A. Sperm action. Prog. reprod. Biol., 1, Karger, Basel.

TSAFRIFI A., LINDNER H. R., ZOR U., LAMPRECHT S. A., 1972. In vitro induction of meiotic division in follicle enclosed rat oocytes, by LH, cyclic AMP and posianglandin $E_{2}$. J. Reprod. Fert., 31, 39-50.

TSAFRIFI A., LIEBERMAN M. E., AHRÉN K., LINDNER H. R., 19760. Dissociation between LH induced aerobic glycolysis and oocyte maturation in cultured graafian follicles of the rat. Acta endocr., 81, 322-326.

TSAFRIFI A., POMERANTZ S. H., CHANNING C. P., 1976b. Inhibition of oocyte maturation by porcine follicular fluid : partial characterization of the inhibitor. Biol. Reprod., 14, 511-516. 